\title{
Gender and homosexuality attitudes across religious groups from the 1970s to 2014: Similarity, distinction, and adaptation
}

\author{
Landon Schnabel ${ }^{*}, 1$ \\ Indiana University, Bloomington, United States
}

\section{A R T I C L E I N F O}

\section{Article history:}

Received 7 January 2015

Received in revised form 5 September 2015

Accepted 29 September 2015

Available online 9 October 2015

\section{Keywords:}

Public opinion

Attitudes

Religion

Gender roles

Same-sex marriage

Morality of homosexuality

Symbolic boundaries

Culture

Identity

\begin{abstract}
A B S T R A C T
This study uses General Social Survey data to compare gender and homosexuality across American religious groups from the 1970s to 2014, examining three possible patterns for how evangelical attitudes relate to those of other groups: (1) they are similar; (2) they are different, but move together over time; (3) they are different and converge or diverge over time. Evangelical gender attitudes regarding work and family issues are more conservative than those of all other groups, but are adaptive to broad trends, changing at a rate similar to those of other groups. Evangelical attitudes toward the morality of homosexuality and same-sex marriage are more conservative than those of all other religious groups, and their rate of change is slower over time. Separate trends on the two issues suggest that gender and sexuality attitude change is decoupled, especially among evangelicals who are adapting more on gender while increasingly distinguishing themselves on same-sex relationships. A three-stage process of religious tension appears to characterize evangelical identity-building: (1) similarity, (2) distinction, and (3) adaptation.
\end{abstract}

() 2015 Elsevier Inc. All rights reserved.

Should women be supported in the workplace and hold civil leadership positions? Should gay men and lesbians have the right to get married? Gender and sexuality are contentious topics in both private and public debate, sparking conflict in American families, religious communities, and national politics. Examining beliefs about gender and sexuality across religious groups provides an opportunity to consider not only attitude change, but also how social groups distinguish themselves from one another (Edgell, 2012; Lamont and Molnár, 2002). Gender and sexuality are both central for boundary drawing among religious groups and often seem to operate in tandem (Tranby and Zulkowski, 2012), but do American religious groups reveal similar patterns for attitude change on both of these issues? Is it possible that those in conservative Protestant denominations are adapting more on one issue while distinguishing themselves more on the other?

To investigate the questions at hand, I use General Social Survey (GSS) data and a work and family focused gender attitude scale (Cotter et al., 2011) to first compare overall religious group differences and then compare rates of attitude change over time. Following the examination of gender attitudes, I compare them to attitudes toward the morality of homosexuality and same-sex marriage. Though I examine and discuss all major American religious groups, I focus on evangelicals because American evangelicalism exemplifies the drawing of symbolic boundaries-they use moral stances to distinguish the people

\footnotetext{
* Corresponding author. Department of Sociology, Indiana University, 744 Ballantine Hall, 1020 E. Kirkwood Ave., Bloomington, IN 47405, United States. E-mail address: lpschnab@indiana.edu.

1 The author owes special thanks to Clem Brooks, Youngjoo Cha, and especially Brian Powell for frequent support on this project. He would also like to thank Cate Taylor, Lisa Miller, Emily Wurgler, Ariel Sincoff-Yedid, fellow participants in the summer cohort writing group, fellow participants in the S700 writing workshop, and the anonymous reviewers for insightful comments on earlier drafts. This paper was presented at the 2014 annual meetings of Sociologists for Women in Society and the Society for the Scientific Study of Religion.
} 
in their group from those outside their group (Smith et al., 1998; Tranby and Zulkowski, 2012). These examinations will reveal whether conservative religion slows movement toward equality in the realms of gender and sexuality, and whether the liberalization of gender attitudes and sexuality attitudes follow similar or different patterns. The findings demonstrate that evangelical Protestant gender attitudes are more conservative relative to other groups, but have changed at rates similar to other groups-in fact, there has been no clear differentiation in the rate of gender attitude change across religious groups since 1994. Likewise, evangelical Protestant attitudes toward same-sex relationships are more conservative relative to other groups, but they have diverged to become even more distinct over time.

\section{Background}

\subsection{Symbolic boundaries and American evangelicalism}

In the United States, religion is a particularly strong cultural power for shaping beliefs about gender and sexuality (Tranby and Zulkowski, 2012). Culture influences attitudes and action through ideas, symbols, and metaphors that function as tools in a "cultural toolkit" (Swidler, 1986). People draw upon these cultural tools to construct boundaries between themselves and others that demarcate their membership in a worthy and moral group (Edgell et al., 2006; Swidler, 1986). In this construction of boundaries, they draw distinctions between the worthy in-group and the out-group of "others" (Edgell et al., 2006; Edgell, 2012; Tranby and Zulkowski, 2012). These boundaries are moral and symbolic rather than ethnic or material, and thus are labeled symbolic boundaries (Edgell et al., 2006; Lamont and Molnár, 2002; Tranby and Zulkowski, 2012). Lamont and Molnar (2002) defined symbolic boundaries as conceptual distinctions made to categorize objects, practices, people - and even time and space-by which individuals and groups grapple with and eventually agree upon shared definitions of reality. Symbolic boundaries come to take on a "real" character, generating collective identities and separating people into distinct groups.

Sociological research on evangelicals highlights how they seek to be both in the world (adaptation), but not of the world (distinction) (Bartkowski and Read, 2003; Gallagher and Smith, 1999; Heath, 2003; Tranby and Zulkowski, 2012). Symbolic boundary drawing is central to evangelicals' strength because they thrive with a sense of embattlement with secular society even as they adapt to it (Smith et al., 1998). This strength is the type that arises in strict churches that are in tension with the outside world and thus reduce free-riding and foster commitment and vitality (Iannaccone, 1994; Stark and Finke, 2000). Gender and sexuality attitudes are particularly important areas for the drawing of symbolic boundaries, especially for evangelicals (Bartkowski, 2001; Edgell, 2006; Gallagher, 2003 2004; Heath, 2003; Hoffman and Bartkowski, 2008; Tranby and Zulkowski, 2012).

Though evangelicals have constructed marked symbolic boundaries between themselves and other groups-drawing on gender and sexuality as important sites to emphasize cultural distinctions to show that they are not like the rest of the world-evangelical attitudes do seem to be adaptive to social change and broad cultural trends (Edgell, 2006; Wilcox, 2004). Attitude change hints at potential shifts in the drawing of symbolic boundaries. The present study's comparative examination of rates of change in gender and sexuality attitudes across religious groups will help us to better understand not just attitude change on these relevant social issues, but whether and how evangelical symbolic boundaries are adapting to a changing world.

\subsection{Gender attitudes}

American gender attitudes surrounding issues of work and family changed rapidly through the early-1990s, but appeared to stall in the mid-1990s, and were no more egalitarian in 2008 than they were in the early 1990s (Cotter et al., 2011). In light of this slowing of gender attitude liberalization and lack of change in other measures of gender equality - such as occupational segregation (Charles and Grusky 2005)-sociologists have suggested that movement toward gender equality is uneven, has slowed, and may even have stalled (Cotter et al., 2011; England, 2010; Gerson, 2010).

Cotter et al. (2011) argued that a neo-traditional frame of "egalitarian essentialism" had arisen. Such a frame is new, according to Cotter et al. (2011), because it combines some aspects of feminist equality-which distinguishes it from the older "separate spheres" frame-with traditional familism. Egalitarian essentialism asserts that women and men have equal but essentially different natures that make them more or less skilled at different roles. In this frame-which is highly consistent with ideas surrounding intensive mothering and the "opting out" narrative ${ }^{2}$ (Stone 2007)-women are viewed as natural caretakers who are inherently skilled at nurturing. Correspondingly, men are viewed as particularly able to produce in the workforce and provide for their families. In sum, this frame's justification of gender roles moves away from explicit subordination to assumptions about different propensities and skills, and mothering is spoken about as having value equal to, or even greater than, paid labor. Cotter et al. (2011) assert that this frame-by combining conflicting elements of feminism and traditional familism-facilitates a return to traditional gender roles while denying implications of a lower valuing of women.

Such frames could be most prominent among religious groups that promote complementarian theology. Complementarian theology argues that, having been created to complement one another, women and men are essentially different and suited to different roles. Evangelical religious leaders developed the current version of

\footnotetext{
${ }^{2}$ The opting out narrative suggests that women should and do leave professional careers when they have children because they feel naturally driven to be full-time caregivers.
} 
complementarianism-God assigned women and men different, but equal, roles ${ }^{3}$ that complement one another-in the 1970 s in direct response to second-wave feminism (Schnabel, 2015). By combining some elements of feminism-women and men are of equal worth-with complementary (i.e., traditional) gender roles, this religious response to feminism sought to maintain men's leadership role and women's submissive role while denying claims that this means that women and men are unequal. If evangelical religious leaders were successful in imparting this perspective to everyday evangelicals, there should be different patterns of attitude change among evangelicals than among other religious groups. Research on gender and American religion, however, shows that the rhetoric of religious leaders and the everyday beliefs and practices of religious adherents are often only loosely coupled (Denton, 2004; Edgell, 2006; Gallagher, 2003). It is possible, therefore, that everyday evangelicals have not followed the traditional elite discourse, and have liberalized along with other Americans.

\subsubsection{Previous research on religion and American gender attitudes}

Survey research on the relationship between religion and gender attitudes in America finds that conservative religion is linked with conservative gender attitudes and that nonreligion is associated with particularly egalitarian attitudes (Brinkerhoff and MacKie, 1984; 1985; Burn and Busso, 2005; Moore and Vanneman, 2003; Peek et al., 1991). Not only are conservative Protestants less gender egalitarian than the nonreligious, but qualitative research on a Catholic, Black Protestant, and LGBTQ inclusive mainline Protestant congregations has found surprisingly high levels of affirmation for traditional gender roles in these more progressive congregations (Edgell and Docka, 2007). Based on previous research, we know that religion influences gender attitudes, but we do not know how that influence may change over time (but see Petersen and Donnenwerth, 1998 for an older study on attitude change).

\subsection{Attitudes toward same-sex relationships}

Previous research shows that sexuality, like gender, is an important area in which religious people draw symbolic boundaries (Olson et al., 2006; Tranby and Zulkowski, 2012). Rather than examine all available sexuality attitudes, this paper examines particularly relevant attitudes-beliefs about homosexuality and same-sex marriage. In America, religion is central to public debate surrounding same-sex marriage and is particularly salient in the shaping of attitudes toward homosexuality (Adamczyk and Pitt, 2009). Though attitudes toward the morality of homosexuality and same-sex marriage did not start changing as early as did gender attitudes, they now appear to be consistently liberalizing to the apparent dismay of many conservative religious leaders and pundits (Baunach, 2011; Loftus, 2001; Powell et al., 2010; Sherkat et al., 2011).

Petersen and Donnenwerth (1998) compared gender attitudes and support for gay rights from the early 1970s to the early 1990s, which is just prior to the stall in gender attitude change noted by Cotter et al. (2011). Using the General Social Survey, they found that all Christian groups liberalized on gay rights and gender attitudes from the 1970s to 1993 (Petersen and Donnenwerth, 1998). During this same period-in which all Christian groups liberalized on limited gay rights-American beliefs on the morality of homosexuality did not liberalize (Loftus, 2001). Analyzing the General Social Survey through 2002, Linneman (2004) found that conservative Christians' views on the morality of homosexuality changed more slowly than people who were not conservative Christians, but conservative Christians' attitudes toward basic gay rights were changing at a similar rate to other Americans. He argued that conservative Christians perceived tension and hostility from lesbians, gay men, and American society in general over LBGTQ issues, believed that their conservative Christian values were marginalized, and therefore changed their views toward the morality of homosexuality more slowly. In a study focused on California, Lewis and Gossett (2008) used news polls to examine attitude change on same-sex marriage. They found that Protestant's attitudes changed more slowly than those of other religious groups.

In more recent years, the General Social Survey has included a measure of support for same-sex marriage. Not only is religion an important factor for understanding American attitudes toward same-sex marriage, but Olson et al. (2006) found that it has a stronger influence than sociodemographic characteristics and Perry (Forthcoming) found that conservative religious identity predicts stronger opposition to same-sex marriage than belief in inerrancy, belief in creationism, and frequency of bible reading. Sherkat and colleagues (Sherkat et al., 2010; Sherkat et al., 2011) have used the same-sex marriage measure to show that religion is a strong predictor for negative views of homosexuality and opposition to same-sex marriage, and that the influence of religion may be increasing over time. Similarly, Baunach $(2011,2012)$ found that opposition to samesex marriage was higher among all groups in 1988, and that groups-such as evangelicals, Republicans, Southerners, and Blacks-began to become more distinct from other Americans over time.

Other research, however, indicates that evangelical attitudes are changing more quickly than suggested by the aforementioned literature. Conservative religious groups are now more willing to extend limited civil rights (e.g., freedom of speech) to gay men and lesbians than they were in the past (Kenneavy, 2012). Similarly, Bean and Martinez (2014) found that while many active evangelicals still view gay men and lesbians as immoral, some of them are open to the idea of civil unions. Nevertheless, conservative religion is still one of the most important predictors for opposition to same-sex marriage in America (Powell et al., 2010).

\footnotetext{
${ }^{3}$ The theological literature promoting this perspective uses the term "role" to make this point. Furthermore, much of the gender attitude literature also uses the term (Cotter et al., 2011). Therefore, I use it at times for convenience and comparability while recognizing that it has been problematized as presenting an overly static view of gender.
} 


\subsection{The relationship between gender and same-sex relationship attitudes}

Much of the literature tends to suggest that beliefs and attitudes about gender roles and same-sex relationships map closely onto one another (McVeigh and Diaz, 2009; Tranby and Zulkowski, 2012), are inseparable parts of polarized worldviews (Luker, 2006), and operate in tandem (Kenneavy, 2012). The relationship, however, may not be as straightforward as it seems.

In some cases, gender and sexuality attitudes appear to shift differently over time. Whereas a large part of gender attitude change can be explained by generational change (Brooks and Bolzendahl, 2004; Pampel, 2011; Schnittker et al., 2003), Baunach (2011) showed that much of the recent rapid rise in support for same-sex marriage is due to intracohort change-or people changing their views over time-rather than younger generations replacing older generations. ${ }^{4}$ Other studies have discussed how gender and sexuality attitudes are heterogeneous, suggesting that they are related, but in complex ways (Bolzendahl and Myers, 2004; Schnittker et al., 2003). One recent study explicitly argued that value issues are not always aligned, using abortion and gay rights attitudes to highlight attitude asynchrony (Dillon, 2014). Finally, some research has suggested that future studies might be able to uncover a decoupling of rates of change in gender and sexuality attitudes across religious groups (Powell et al., 2010). In other words, one set of beliefs could change more quickly than the other even in the presence of a continued correlation between the attitudes, and the relative rates of change could differ across religious groups.

\subsection{Expectations}

This study uses the General Social Survey to examine change in gender and sexuality attitudes over time across religious groups to assess whether they reveal similar or divergent trends. Three competing patterns of attitude change are possible and will be considered, first for gender attitudes and then for sexuality attitudes:

(1) Evangelical attitudes could be similar to those of other groups. In this case, evangelical attitudes would be just as egalitarian as those of other groups, and their attitudes would move along with other groups to maintain this similarity.

(2) Evangelicals could have more conservative attitudes overall, but move along with everyone else. In this case, their attitudes would be distinctive at individual points in time, but adaptive to broad social forces over time, changing just as rapidly as those of other religious groups.

(3) Evangelical attitudes could be distinctive and change at a different rate than that of other groups. If evangelical attitudes change more slowly than other groups, they would become increasingly different over time.

Gender and sexuality attitudes could fit the same pattern, or they could follow different patterns. If evangelicals have adapted their attitudes more in one area and come to distinguish themselves more in the other, it would not only suggest a decoupling of change in gender and sexuality attitudes, but also a remapping of symbolic boundaries-or how evangelicals are distinguishing themselves from the broader culture.

\section{Data, measures, and methods}

\subsection{Data}

I use General Social Survey (GSS) data to analyze gender attitude and sexuality attitude change across religious categories. The NORC General Social Survey is a probability-based face-to-face interview sampling of non-institutionalized U.S. adults 18 and older, fielded from 1972 through 2014. Following recent work on gender attitude change (Cotter et al., 2011), I examine four key gender attitude measures ${ }^{5}$ that have been consistently asked from 1977 to $2014(\mathrm{~N}=21,435){ }^{6}$ Separate samples are used for corresponding analyses of attitudes toward the morality of homosexuality (asked from 1973 to $2014 ; \mathrm{N}=29,983$ ) and support for same-sex marriage measures (asked in 1988 and then again from 2004 to 2014; $\mathrm{N}=8785$ ).

\subsection{Dependent variables}

\subsubsection{Gender attitudes scale}

This study uses the same standardized gender attitudes scale-constructed by standardizing and then summing scores for each of four gender attitude measures (Cronbach's $\alpha=0.70$ ) - used by Cotter et al. (2011). Using the same scale allows for comparison with, and extension of, Cotter and colleagues' findings. Three items ask the respondent whether and how strongly $\mathrm{s} /$ he agrees (strongly disagree $=1$ to strongly agree $=4$ ) with the following statements:

\footnotetext{
${ }^{4}$ Generational change does still account for a significant portion of the change in same-sex marriage attitudes (Sherkat et al., 2011).

5 There are other repeated questions in the GSS, but the survey stopped asking them in 1998.

${ }^{6}$ I do not include the 1982 and 1987 Black oversamples, and restrict my analyses to respondents for whom complete data are available, losing $10.2 \%$ of the total 23,874 for missing controls, primarily due to the income measure. As a sensitivity test, I used a multiple imputation method-Gaussian normal regression imputation-to replace missing values and arrived at substantively equivalent results across models.
} 
- "A working mother can establish just as warm and secure a relationship with her children as a mother who does not work."

- "A preschool child is likely to suffer if his or her mother works."

- "It is much better for everyone involved if the man is the achiever outside the home and the woman takes care of the home and family."

These are coded so that higher values are more egalitarian. The other measure is dichotomous, asking the respondents whether they agree (disagree $=1$ ) with the following statement:

- "Most men are better suited emotionally for politics than are most women."

Taken together, these four variables provide a good measure-the best available for comparing attitude change from the 1970s to the present-of a respondent's level of gender essentialism and her/his attitudes about gender roles, especially in regard to work and family issues. See Table 1 for descriptive statistics for this measure and the others included in this study.

Table 1

Descriptive statistics.

\begin{tabular}{|c|c|c|c|c|}
\hline Measures & Metric & Mean & SD & Range \\
\hline \multicolumn{5}{|l|}{ Dependent Variables } \\
\hline Gender Attitudes Scale & Standardized and Summated & 0.013 & 0.726 & -1.922 to 1.297 \\
\hline $\begin{array}{l}\text { A working mother can establish just } \\
\text { as warm and secure a relationship } \\
\text { with her children as a mother } \\
\text { who does not work. }\end{array}$ & Strongly Disagree $=1$ to Strongly Agree $=4$ & 2.840 & 0.880 & $1-4$ \\
\hline $\begin{array}{l}\text { A preschool child is likely to suffer } \\
\text { if his or her mother works. }\end{array}$ & Strongly Agree $=1$ to Strongly Disagree $=4$ & 2.559 & 0.808 & $1-4$ \\
\hline $\begin{array}{l}\text { It is much better for everyone } \\
\text { involved if the man is the achiever } \\
\text { outside the home and the woman } \\
\text { takes care of the home and family. }\end{array}$ & Strongly Agree $=1$ to Strongly Disagree $=4$ & 2.720 & 0.857 & $1-4$ \\
\hline $\begin{array}{l}\text { Most Men are better suited } \\
\text { emotionally for politics } \\
\text { than are most women. }\end{array}$ & Disagree $=1$ & 0.741 & & \\
\hline Morality of Homosexuality & $\begin{array}{l}\text { Always Wrong }=1 \text {, Almost Always } \\
\text { Wrong }=2 \text {, Sometimes Wrong }=3 \\
\text { Not Wrong at All }=4\end{array}$ & 1.920 & 1.294 & $1-4$ \\
\hline Support for Same-Sex Marriage ${ }^{\mathrm{b}}$ & Strongly Disagree $=1$ to Strongly Agree $=5$ & 3.190 & 1.519 & $1-5$ \\
\hline \multicolumn{5}{|l|}{ Religious Category } \\
\hline Evangelical & Evangelical $=1$ & 0.263 & & \\
\hline Black Protestant & Black Protestant $=1$ & 0.080 & & \\
\hline Mainline & Mainline $=1$ & 0.207 & & \\
\hline Catholic & Catholic $=1$ & 0.248 & & \\
\hline No Affiliation & No Affiliation $=1$ & 0.128 & & \\
\hline Jewish & Jewish $=1$ & 0.020 & & \\
\hline Other Faith & Other Faith $=1$ & 0.054 & & \\
\hline \multicolumn{5}{|l|}{ Survey Year } \\
\hline Year Spline (1977-1994) & $1977=0$ to $1994=17 ;$ All Following Years $=17$ & 14.261 & 4.642 & $0-17$ \\
\hline Year Spline (1994-2000) & $1977-1994=0$ to $2000=6 ;$ All Following Years $=6$ & 2.922 & 2.808 & $0-6$ \\
\hline Year Spline (2000-2014) & $1977-2000=0$ to $2014=14$ & 3.050 & 4.710 & $0-14$ \\
\hline \multicolumn{5}{|l|}{ Controls } \\
\hline Female & Female $=1$ & 0.562 & & \\
\hline \multicolumn{5}{|l|}{ Race } \\
\hline White & White $=1$ & 0.811 & & \\
\hline Black & Black $=1$ & 0.130 & & \\
\hline Other & Other $=1$ & 0.059 & & \\
\hline Age in Decades & In Decades & 4.535 & 1.684 & $1.8-8.9$ \\
\hline Parental Status & Parent $=1$ & 0.725 & & \\
\hline Marital Status & Married $=1$ & 0.513 & & \\
\hline Female Work Status & $\begin{array}{l}\text { If Female, Working Full Time }=1 \text {; If Male, } \\
\text { Spouse Working Full Time }=1\end{array}$ & 0.347 & & \\
\hline South & South $=1$ & 0.356 & & \\
\hline \multicolumn{5}{|l|}{ Highest Degree Earned } \\
\hline Less Than High School & Less than High School Diploma $=1$ & 0.170 & & \\
\hline High School & High School Diploma $=1$ & 0.521 & & \\
\hline Some College & Some College $=1$ & 0.066 & & \\
\hline Bachelor & Bachelor's Degree $=1$ & 0.163 & & \\
\hline Graduate & Graduate Degree $=1$ & 0.080 & & \\
\hline Family Income & Inflation-Adjusted (2000) Tens-of-Thousands of Dollars & 4.640 & 3.790 & $0.037-18.039$ \\
\hline
\end{tabular}

$\mathrm{N}=21,435$.

a $\mathrm{N}$ for Morality of Homosexuality is 29,983 .

b $\mathrm{N}$ for Support for Same-Sex Marriage is 8785 .

Source: General Social Survey 1977-2014 


\subsubsection{Morality of homosexuality and support for same-sex marriage}

To compare gender attitudes with attitude change toward gay and lesbian Americans, I use a measure of attitudes toward the morality of homosexuality and a measure of support for same-sex marriage. ${ }^{7}$ Fielded consistently since 1973 , the morality of homosexuality question asks respondents: "What about sexual relations between two adults of the same sex-do you think it is (1) always wrong, (2) almost always wrong, (3) wrong only sometimes, or (4) not wrong at all?" Fielded in 1988 and then again from 2004 to 2014, the support for same-sex marriage question asks whether respondents (1) strongly disagree to (5) strongly agree with the following statement: "Homosexual couples should have the right to marry one another."

\subsection{Key independent variables}

\subsubsection{Religious affiliation}

Religious affiliation is measured using the Steensland et al. (2000) religious categorization scheme (RELTRAD), which allows for meaningful comparisons between evangelicals and other religious groups to explore trends in distinction and adaptation. The scheme uses self-reported denominational affiliation to place respondents into seven categories based on the historical development of religious traditions in the United States: evangelical Protestant, Black Protestant, mainline Protestant, Catholic, no affiliation, Jewish, and "other faith."

\subsubsection{Year}

To compare gender attitude change over time, I use a best-fitting spline function with "knots" (or hinges) at the same locations-1994 and 2000 - used by Cotter et al. (2011). A spline function splices lines-specifically, it joins together two or more lines with different slopes. The slopes, "hinged" at statistically driven locations, are then estimated by transforming year so that each period between the hinges can be interpreted as a linear term for that time range. ${ }^{8}$ As Cotter et al. (2011) showed, American gender attitudes "hinge" at 1994 and 2000. As presented in the models, the period coefficients measure the linear change during the indicated interval of time-Year Spline (1977-1994) measures attitude change from 1977 to 1994 . Religious groups are interacted with period terms to compare rates of change within intervals of time.

The same-sex relationship attitudes do not follow the same rise, decline, and subsequent rise pattern of the gender attitudes. For these attitudes, Bayesian Information Criterion (BIC) scores prefer the simpler model with a linear interaction term for year and religious groups rather than interaction terms for spline intervals and religious groups (Raftery, 1995). Whereas the pattern of gender attitude change required a spline function, a straightforward linear term for year is appropriate for sexuality attitude change, already suggesting that the general population follows a different attitude change pattern on these attitudes. ${ }^{9}$ Religious groups are interacted with year to compare change from 1973 to 2014 for morality of homosexuality and from 1988 to 2014 for same-sex marriage.

\subsection{Demographic controls}

This study takes into account key demographic controls that may affect gender and sexuality attitudes. These items were selected based on theory and what is standard in the literature (Bartkowski and Hempel, 2009; Cotter et al., 2011). These measures were then tested using BIC scores to determine whether they should be included (Raftery, 1995). Controls include sex $($ female $=1)$, race (white $=1$, Black $=2$, other $=3),{ }^{10}$ age (in years), parental status (parent $=1$ ), marital status (married $=1$ ), female work status (coding explained below), region (South $=1$ ), education (dummies for highest degree

\footnotetext{
7 There are three other questions in the GSS - as part of a sequence of questions on speech rights for different groups, such as atheists, Muslims, and communists - that ask about whether a gay man should be allowed to speak in a community, whether he should be able to hold a position at a college, and whether a gay-friendly book should be allowed to stay at the public library. These questions, while interesting and important, are less about sexuality (and more about free speech) than the two questions this paper examines-which are particularly relevant to current political debate. Furthermore, the rights questions have limited variability, especially among more liberal religious groups, such as Jews and the unaffiliated, who already revealed very high support for these minimal rights in the 1970s.

${ }^{8}$ I used the default mkspline command in Stata 13 for the spline function with hinges at 1994 and 2000. The first interval in the spline function, 1977-1994, is coded as 0 for 1977 and increases by one for each year until 1994, which is 17.17 is then the value for 1994 and all following years. The second interval, 1994-2000, is 0 until 1994 and then increases by one for each year until 2000, which is 6, and 6 is then the value for 2000 and all following years. The third interval, 2000-2014, is coded as 0 for all years until 2000 and then increases by one for each year until the final year in the sample 2014, where it has a value of 14. Cotter et al. (2011) coded their spline function variables so that the year term does not stop increasing by one for every year once the next knot is reached (in Stata, this is done by using the margin option with the mkspline command). Rather than providing the linear term for year within a period of time, their approach tested the rate of change against the immediately previous interval, limiting their ability to compare the rate of change after 2000 to the rate of change before 1994.

${ }^{9}$ I conducted a sensitivity analysis with a spline function for the morality measure with a knot at 1994 to parallel the gender attitudes analyses and another analysis with a knot at 1990 when attitudes toward the morality of homosexuality began to steadily rise. The patterns for group change were substantively similar to the linear model.

10 Although the Black Protestant religious affiliation category and Black race category are correlated at .7, I control for race to ensure that I measure the impact of Black Protestantism rather than just racial attitude differences. Scholars have been concerned about collinearity when including both Black Protestantism and race in the same model, but a follow-up to the Steensland et al. (2000) religious categorization scheme argues that collinearity should not be a problem when using large surveys such as the GSS (Woodberry et al., 2012). Sensitivity analyses not controlling for race reveal substantively equivalent findings for rates of attitude change over time across religious categories.
} 
attained), and family income (inflation-adjusted to 2000 and expressed in tens-of-thousands of dollars). Female work status is coded 1 if a female respondent works full time and if a married male respondent indicates that his spouse works full time. ${ }^{11}$

\subsection{Analytic strategy}

Following Cotter et al. (2011), this study uses ordinary least squares (OLS) regression for the gender attitudes scale. ${ }^{12}$ Ordinal logistic regression is used for the morality of homosexuality and support for same-sex marriage measures. All outcomes are estimated using Huber/White sandwich robust standard errors. All analyses are unweighted. ${ }^{13}$ Sensitivity analyses including weights yielded substantively equivalent results.

I first compare religious group main effects on gender attitudes. Second, I present figures that show gender attitude change across groups based on separate models for each year with centered covariates. I then include all years in the same model (the primary method as described above) and interact religious groups with best-fitting spline function interval terms to compare rates of change during three periods of time. Subsequently, I present the parallel analyses of attitudes toward the morality of homosexuality and support for same-sex marriage. Finally, I present a linear analysis of gender attitudes for the sake of easier comparison with the sexuality attitude analysis, and to examine whether there has been a consistent gender attitude liberalization trend since the start of the "stall" noted by Cotter et al. (2011) (Table 1).

\section{Results}

\subsection{Gender attitudes}

\subsubsection{Gender attitudes across religious groups}

Table 2 presents religious group affiliation effects with just controls for survey year ${ }^{14}$ (Model 1 ) and then affiliation effects with demographic controls added (Model 2). Evangelical is the reference category. In Model 1, all religious categories are more egalitarian than evangelicals $(p<.001)$. For example, the unaffiliated $(b=.352, p<.001)$ are half a standard deviation of the gender attitude scale more egalitarian than evangelicals. Evangelical attitudes are clearly distinctive, being more conservative than those of all other groups.

In the spline function, the 1977 to 1994 interval measures attitude change during this time period. Similarly, 1994 to 2000 and 2000 to 2014 measure change during these time periods. Gender attitudes have become more egalitarian since the 1970s except for a period from 1994 to 2000 when they became less egalitarian $(b=-.025, p<.001)$.

Model 2, which includes demographic controls, shows that, with one exception, the religious affiliation differences are not attributable to sociodemographic differences. All but the "other faith" category are still more egalitarian $(p<.001)$ than evangelicals. Consistent with the literature, women are more egalitarian than men $(b=.200, p<.001)$. The gender attitudes of Black Americans do not differ significantly from whites. ${ }^{15}$ Those in the "other race" category are less egalitarian than whites $(b=-.186, p<.001)$. People who are older, married, or from the South are less egalitarian $(p<.001)$, whereas parents, working women or men married to working women, people with more education, and those with a higher income are more egalitarian $(p<.001) \cdot{ }^{16}$ The 2000-2014 year interval shows that attitudes are currently liberalizing and that this change is not attributable to sociodemographic shifts $(b=.020, p<.001)$.

Affiliation effects decrease with the inclusion of demographic controls, but they persist and can be compared to demographic characteristics. Being an evangelical, when compared to those with no religious affiliation $(b=.249, p<.001)$ or Jews $(b=.313, p<.001)$, has a larger effect than gender $(b=.200, p<.001)$. In fact, being evangelical, in comparison to the most liberal groups, has a larger effect than all demographics except having a bachelor's degree $(b=.272, p<.001)$-about the same magnitude as being evangelical compared to the unaffiliated and Jews-or having a graduate degree $(b=.413, p<.001)$.

In sum, evangelicals are the least egalitarian religious group and religion is a stronger predictor of gender attitudes than all measures but education, suggesting that gender attitudes are an important field for drawing symbolic boundaries and expressing evangelical collective identity. This still leaves open the question of whether the first or third possible expectation fits the data: are evangelical attitudes changing more slowly than other groups (expectation 1 ), or are they adapting to broad social change at the same rate as other groups (expectation 3 )?

\footnotetext{
11 I use the same female work status coding method used by Bartkowski and Hempel (2009). Though this control is not as standard to the literature as the others, its inclusion is supported by BIC tests. Sensitivity analyses without this measure provided substantively equivalent results.

12 I conducted sensitivity analyses using ordinal logistic regression with the same models and the results were substantively equivalent.

13 Winship and Radbill (1994) showed that unweighted regression estimates tend to be unbiased and consistent when using large surveys with weights that are solely a function of independent-rather than dependent-variables.

${ }^{14}$ Sensitivity analyses using BIC tests show that dummy variables for year are very strongly preferred for fit over just a linear term for year. However, including the best-fit spline with knots at 1994 and 2000, the method presented, is very strongly preferred by BIC tests over year dummy variables.

${ }^{15}$ A model (not shown) including the demographics, but not the independent variable (religious affiliation), shows that Blacks are significantly more egalitarian than whites. This effect is no longer significant with the inclusion of religious categories.

${ }^{16}$ In sensitivity analyses, I included measures of religious belief (biblical literalism, which is not available for all years) and practice (attendance). More literal views of the Bible and more frequent religious service attendance are both associated with less egalitarian gender attitudes. Including these measures in the models decreases overall group difference, but leads to substantively equivalent findings for rates of change over time.
} 
Table 2

Regression of group membership effects on gender attitudes scale.

\begin{tabular}{lll}
\hline & Model 1 & Model 2 \\
\hline Religious Categories & & - \\
Evangelical & - & $0.149^{* * *}(0.023)$ \\
Black Protestant & $0.219^{* * *}(0.019)$ & $0.161^{* * *}(0.013)$ \\
Mainline & $0.182^{* * *}(0.014)$ & $0.126^{* * *}(0.013)$ \\
Catholic & $0.170^{* * *}(0.014)$ & $0.249^{* * *}(0.015)$ \\
No Affiliation & $0.352^{* * *}(0.016)$ & $0.313^{* * *}(0.032)$ \\
Jewish & $0.437^{* * *}(0.035)$ & $0.012(0.023)$ \\
Other Faith & $0.080^{* * *}(0.024)$ & \\
Survey Year & & $0.030^{* * *}(0.001)$ \\
Year Spline (1977-1994) & $0.034^{* * *}(0.001)$ & $-0.026^{* * *}(0.003)$ \\
Year Spline (1994-2000) & $-0.025^{* * *}(0.003)$ & $0.020^{* * *}(0.001)$ \\
Year Spline (2000-2014) & $0.017^{* * *}(0.001)$ & \\
Controls & & $0.200^{* * *}(0.009)$ \\
Female & & - \\
White & & $0.030(0.018)$ \\
Black & & $-0.186^{* * * *}(0.019)$ \\
Other & & $-0.098^{* * *}(0.003)$ \\
Age in Decades & & $0.044^{* * *}(0.011)$ \\
Parental Status & & $-0.124^{* * *}(0.010)$ \\
Marital Status & & $0.203^{* * *}(0.010)$ \\
Female Work Status & & $-0.078^{* * *}(0.010)$ \\
South & & - \\
Less Than High School & & $0.158^{* * *}(0.013)$ \\
High School & & $0.228^{* * *}(0.021)$ \\
Some College & & $0.272^{* * *}(0.017)$ \\
Bachelor & & $0.413^{* * *}(0.020)$ \\
Graduate & & $0.009^{* * *}(0.001)$ \\
Family Income & & -0.407 \\
Constant & & 21,435 \\
$N$ & & 0.224 \\
$R^{2}$ & & 41880.434 \\
BIC & &
\end{tabular}

Note: Standard errors in parentheses; Models estimated with robust standard errors.

${ }^{*} p<.05,{ }^{* *} p<.01,{ }^{* * *} p<.001$ (two-tailed).

Source: General Social Survey 1977-2014

\subsubsection{Gender attitudes across religious groups over time}

Fig. 1 shows gender attitudes from 1977 to 2014 for all Americans and then for Protestant religious groups, controlling for demographics with centered covariates. These plotted values are based on separate OLS regression models (not shown) for each year with centered controls (the same sociodemographic measures included in Tables $2-4$ ). ${ }^{17}$ We see in Fig. $1 \mathrm{a}$ that the overall gender attitude trend was rapid change in the 1970s and 1980s with decline in the 1990s. From 2000 onward, attitudes have become increasingly egalitarian. As noted by Cotter et al. (2011), the attitudes of all Americans in 2008 had not risen much above the level in the early 1990s. Challenging the idea that American gender attitudes have stagnated, however, in 2010, in 2012, and again in 2014 Americans' attitudes became more egalitarian than ever before.

Fig. 1b shows that evangelical attitudes have followed the same general trend of all Americans, liberalizing until the mid1990s, declining through 2000, and then rising again since 2000. Evangelicals started out closer to the average in the late 1970s, diverged in the late 1980s, and have generally paralleled average American attitude change since then. Mainline Protestants have also followed the same general pattern, as revealed in Fig. 1c. Mainline Protestants, however, have remained much closer to the average, diverging from evangelicals in the late 1980s. Black Protestants also followed a similar pattern, though with more year-to-year volatility because they make up a smaller portion of the sample. ${ }^{18}$ All Protestant groups followed the same trend, paralleling the average for all Americans. They liberalized quickly from the late 1970s to the mid1990s, when they became more traditional. Since 2000, their attitudes have become more egalitarian.

Fig. 2 shows the gender attitudes by year for Catholics, the unaffiliated, Jews, and those in the "other faith" category. Catholic attitudes, like those of mainline Protestants, are similar to the average and move in conjunction with the general population. The unaffiliated are generally more egalitarian than the American average, but again follow the same trend. The

\footnotetext{
17 When using OLS regression to compare groups with centered covariates, the intercept is the value of the excluded group and the coefficients for other groups can be added to the intercept for their predicted values. I used separate models for each year with religious groups to get the values for each group and then a model without religious groups and binary variables for each year to ascertain the yearly values for all Americans.

18 Sensitivity analyses of the figures without controls reveal substantively equivalent patterns of change over time across groups. Without controls, including the one for race, Black Protestants appear slightly more egalitarian than the average, but follow the same pattern over time.
} 


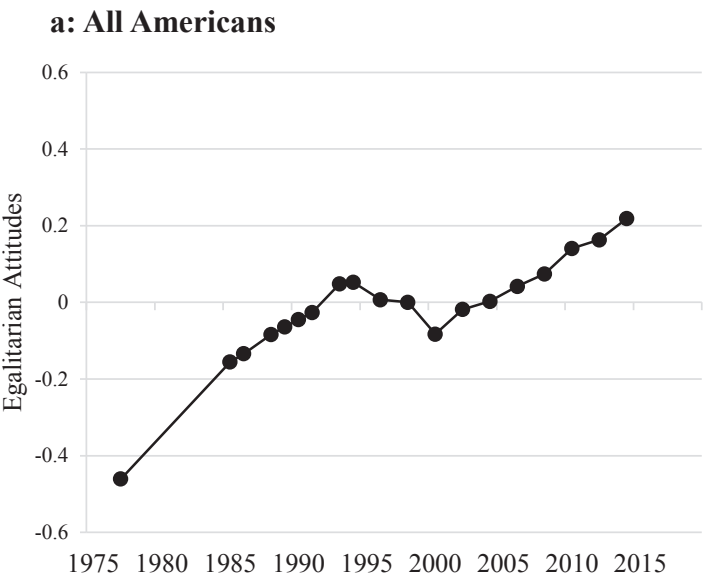

c: Mainline vs. All

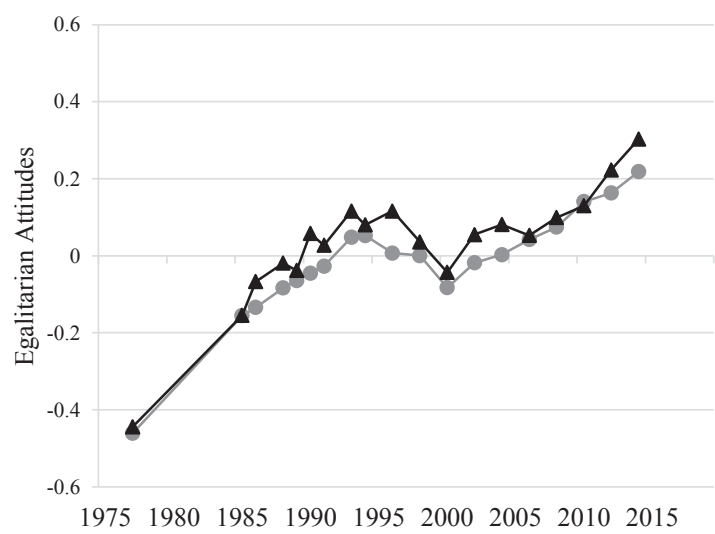

b: Evangelicals vs. All

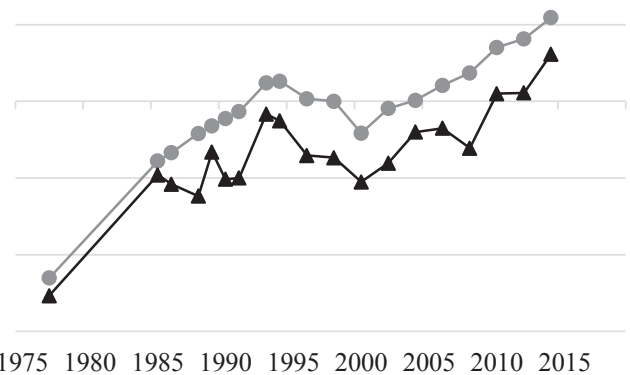

d: Black Protesant vs. All

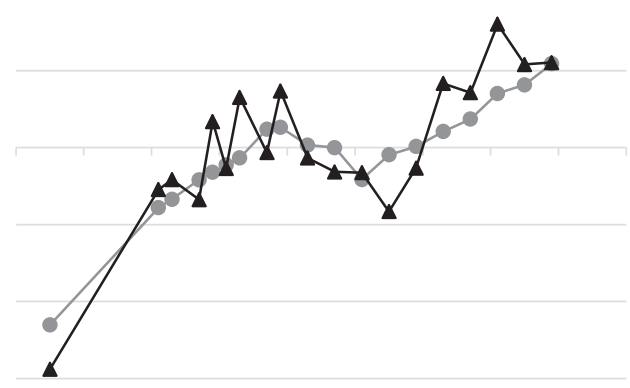

197519801985199019952000200520102015

Fig. 1. Gender Attitude Scale over Time: All Americans and Protestants.

Source: General Social Survey, 1977-2012; Source: General Social Survey, 1977-2014

Jewish and "other faith" categories are very small, and thus unstable and not particularly meaningful. ${ }^{19}$ That said, they do not seem follow the same gender attitude change trend as other Americans. Jews start out quite egalitarian and are typically more egalitarian than other groups, without a clear pattern of change over time. The "other faith" category contains disparate groups and thus their trends cannot be meaningfully interpreted. In sum, Figs. 1 and 2 show that most religious groups followed a similar upward, downward, and then upward trend.

By including all years in the same models presented in Table 2 and interacting religious groups with time periods, we can more explicitly test rates of change during the move toward egalitarianism from 1977 to 1994, during the decline from 1994 to 2000, and during the resurgence of gender attitude change from 2000 to 2014. Table 3 presents coefficients for the effect of year and period on gender attitudes with evangelical as the reference category. These values represent the overall rate of group change during the move toward egalitarianism from 1977 to 1994, the decline from 1994 to 2000, and the resurgence of attitude change from 2000 onward.

Model 1 (without controls) and Model 2 (with controls) of Table 3 demonstrate similar rates of attitude change over time after 1994. Interaction effects for religious groups and time period in Model 2 show that from 1977 to 1994 mainline Protestant $(b=.009, p<.05)$ and Catholic $(b=.010, p<.01)$ attitudes liberalized more rapidly than those of evangelicals. The interaction of religious group and the 1994 to 2000 time period demonstrates that evangelical decline in egalitarianism in this period did not differ from that of other Christian groups or the unaffiliated. The "other faith" $(b=.042, p<.01)$ category operated differently, but that is because, as shown in Fig. 2, they did not follow the same pattern as other groups. The interaction effects for the interval from 2000 to 2014 show that evangelicals have liberalized just as quickly as other Christian groups and the unaffiliated since 2000. In fact, before sociodemographic controls are taken into account, evangelical attitudes

\footnotetext{
${ }^{19}$ Despite their year-to-year volatility, I present these figures for Jewish and "other faith" attitudes to provide context for the interaction effects between year and these groups in Table 3.
} 
Table 3

Interaction effects of membership and year on gender attitudes scale. ${ }^{a}$

\begin{tabular}{|c|c|c|}
\hline & Model 1 & Model 2 \\
\hline \multicolumn{3}{|l|}{ Main Effects } \\
\hline Evangelical & - & - \\
\hline Black Protestant & $0.154^{*}(0.072)$ & $0.121(0.065)$ \\
\hline Mainline & $0.105^{*}(0.048)$ & $0.041(0.043)$ \\
\hline Catholic & $0.045(0.050)$ & $-0.005(0.045)$ \\
\hline No Affiliation & $0.485^{* * *}(0.071)$ & $0.351^{* * *}(0.064)$ \\
\hline Jewish & $0.546^{* * *}(0.117)$ & $0.443^{* * *}(0.099)$ \\
\hline Other Faith & $0.012(0.106)$ & $-0.055(0.101)$ \\
\hline Year Spline (1977-1994) & $0.030^{* * *}(0.003)$ & $0.026^{* * *}(0.003)$ \\
\hline Year Spline (1994-2000) & $-0.030^{* * *}(0.006)$ & $-0.030^{* * *}(0.005)$ \\
\hline Year Spline (2000-2014) & $0.023^{* * *}(0.003)$ & $0.024^{* * *}(0.003)$ \\
\hline \multicolumn{3}{|l|}{ Year Spline (1977 to 1994) Interaction Effects } \\
\hline Evangelical*Year Spline (1977-1994) & - & - \\
\hline Black Protestant*Year Spline (1977-1994) & $0.003(0.006)$ & $0.002(0.005)$ \\
\hline Mainline*Year Spline (1977-1994) & $0.005(0.004)$ & $0.009^{*}(0.003)$ \\
\hline Catholic*Year Spline (1977-1994) & $0.011^{* *}(0.004)$ & $0.010^{* *}(0.004)$ \\
\hline No Affiliation*Year Spline (1977-1994) & $-0.008(0.005)$ & $-0.006(0.005)$ \\
\hline Jewish*Year Spline (1977-1994) & $-0.011(0.009)$ & $-0.013(0.008)$ \\
\hline Other Faith*Year Spline (1977-1994) & $0.001(0.008)$ & $0.001(0.008)$ \\
\hline \multicolumn{3}{|l|}{ Year Spline (1994 to 2000) Interaction Effects } \\
\hline Evangelical*Year Spline (1994-2000) & - & - \\
\hline Black Protestant*Year Spline (1994-2000) & $0.009(0.011)$ & $0.001(0.010)$ \\
\hline Mainline*Year Spline (1994-2000) & $0.004(0.009)$ & $-0.001(0.008)$ \\
\hline Catholic*Year Spline (1994-2000) & $-0.002(0.008)$ & $0.003(0.007)$ \\
\hline No Affiliation*Year Spline (1994-2000) & $0.007(0.010)$ & $0.005(0.009)$ \\
\hline Jewish*Year Spline (1994-2000) & $0.036(0.020)$ & $0.034(0.018)$ \\
\hline Other Faith*Year Spline (1994-2000) & $0.044^{* *}(0.014)$ & $0.042^{* * *}(0.013)$ \\
\hline \multicolumn{3}{|l|}{ Year Spline (2000 to 2014) Interaction Effects } \\
\hline Evangelical*Year Spline (2000-2014) & - & - \\
\hline Black Protestant*Year Spline (2000-2014) & $-0.003(0.006)$ & $-0.001(0.005)$ \\
\hline Mainline*Year Spline (2000-2014) & $-0.002(0.005)$ & $0.001(0.004)$ \\
\hline Catholic*Year Spline (2000-2014) & $-0.009^{*}(0.004)$ & $-0.006(0.004)$ \\
\hline No Affiliation*Year Spline (2000-2014) & $-0.008(0.004)$ & $-0.007(0.004)$ \\
\hline Jewish*Year Spline (2000-2014) & $-0.023^{*}(0.011)$ & $-0.015(0.010)$ \\
\hline Other Faith*Year Spline (2000-2014) & $-0.026^{* * *}(0.007)$ & $-0.021^{* *}(0.007)$ \\
\hline Controls $^{\mathrm{a}}$ & No & Yes \\
\hline Constant & -0.558 & -0.344 \\
\hline$N$ & 21,435 & 21,435 \\
\hline$R^{2}$ & 0.078 & 0.226 \\
\hline BIC & 45635.982 & 42004.611 \\
\hline
\end{tabular}

Note: Standard errors in parentheses; Models estimated with robust standard errors.

${ }^{*} p<.05,{ }^{* *} p<.01,{ }^{* * *} p<.001$.

a Controls are female, race, age, parental status, marital status, female work status, region, education, and family income. Control values are almost identical to those in Table 2.

Source: General Social Survey 1977-2014

actually changed more quickly than Catholic attitudes $(b=.009, p<.05)$. When controls are included in the model, just the disparate "other faith" category is different from evangelicals $(b=-.021, p<.05)$.

Although one might expect evangelical attitude change to be slower than that of other groups based on the rhetoric of evangelical public figures, Table 3 showed that evangelical attitudes changed just as quickly-upward from 1977 to 1994 , downward from 1994 to 2000, and upward again from 2000 onward-as those of other Christians and the unaffiliated. The only noteworthy difference was that mainline Protestants and Catholics liberalized more quickly from 1977 to 1994 . Since then, evangelical attitudes have paralleled those of other Christian groups and the unaffiliated. In sum, gender attitude change has not stagnated and evangelical attitudes are changing at a rate similar to that of other groups. Gender attitudes follow the second possible pattern set forth in the expectations: similar rates of change but continued difference; or, in other words, adaptation over time with distinction at any given point in time.

\subsection{Attitudes toward same-sex relationships}

The gender attitudes of all Christian groups and the unaffiliated moved in parallel to one another. But did attitudes toward gay men and lesbians follow a similar pattern? Figs. 3 and 4 present the yearly means for all Americans, the unaffiliated, and evangelicals on attitudes toward the morality of homosexuality and same-sex marriage. On belief in morality, we see that attitudes are relatively stagnant from the early 1970s to the early 1990s. In the mid-1990s, a continuing upward trend toward accepting same-sex relationships as moral starts among all Americans, the same period in which gender attitudes declined. 
a: Catholic vs. All

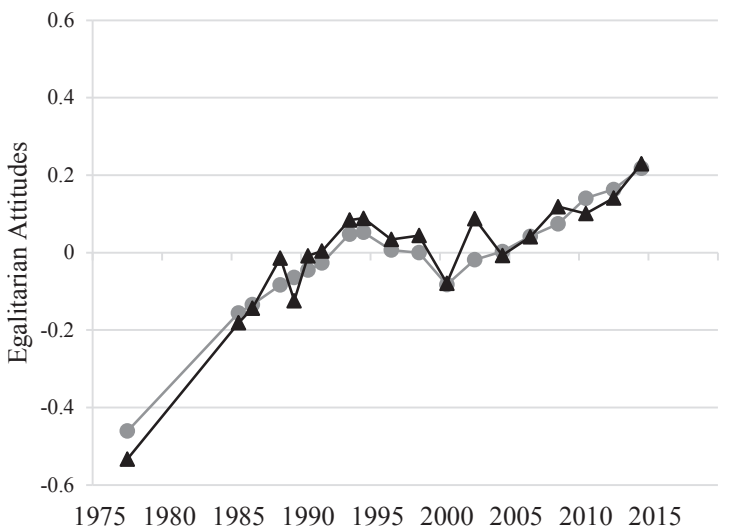

c: Other Faith vs. All

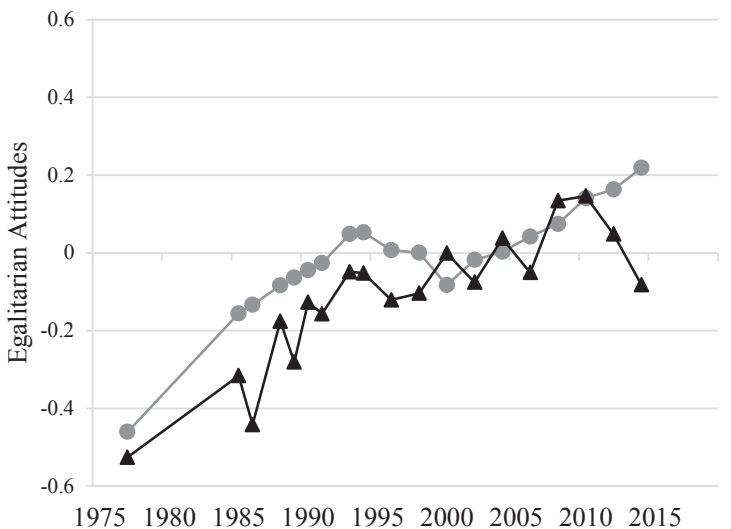

b: No Affiliation vs. All

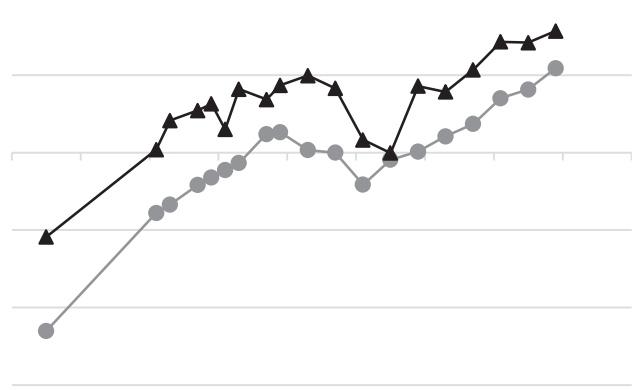

197519801985199019952000200520102015 d: Jewish vs. All

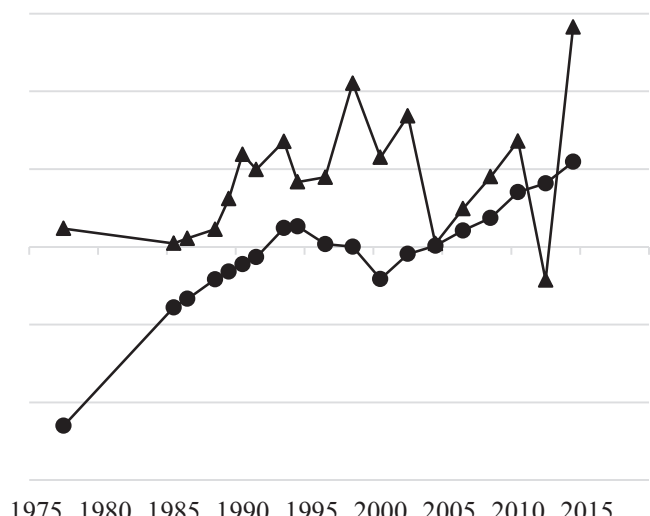

Fig. 2. Gender Attitude Scale over Time: Catholic, Unaffiliated, Other Faith, and Jewish. Source: General Social Survey, 1977-2012; Source: General Social Survey, 1977-2014

Evangelicals and the unaffiliated follow a similar trend: stable attitudes through the mid-1990s and then an upward trend. The evangelical shift, however, appears to be slower than that of the religiously unaffiliated and the general population. Evangelicals start out closer to the American average when most people were opposed to same-sex relationships, but as society liberalized evangelical attitudes diverge. Mainline Protestants and Catholics (not shown) closely follow the American average. $^{20}$

Although fewer years are available, we see a similar pattern on support for same-sex marriage: slower change early on and more rapid change in recent years. Evangelical attitudes again start out closer to the average and then appear to be changing more slowly than those of others. This trend already suggests both that gender and sexuality followed clearly different patterns overall, and that attitudes toward same-sex relationships may be becoming more important for expressing a distinctive evangelical collective identity in opposition to secular society. The uptick for evangelical support for same-sex marriage in 2014, however, may indicate that what has happened in the past could shift in the future.

Table 4 shows overall religious group differences and then differences in rates of change over time on attitudes toward homosexuality and same-sex marriage. Evangelical is the reference category. With only a control for year in Model 1, evangelicals are more conservative $(\mathrm{p}<.001)$ than all but Black Protestants on the morality of homosexuality. When all controls are included in Model 2, evangelicals are more conservative than all other religious groups $(p<.001)$, including Black Protestants. On support for same-sex marriage, evangelicals are more conservative than all religious groups ( $p<.001$ ), both without (Model 4) and with controls (Model 5). Similar patterns show up across both outcome measures, with the unaffiliated and Jewish categories revealing the largest difference from evangelicals. Year is significant $(p<.001)$ for all models, revealing

\footnotetext{
${ }^{20}$ Groups not shown for clarity and parsimony generally parallel the attitudes of one of these three groups on both the morality of homosexuality and support for same-sex marriage. Jewish attitudes are similar to those of the unaffiliated, mainline Protestant and Catholic attitudes are similar to the average, and Black Protestant attitudes are similar to those of evangelicals.
} 
4

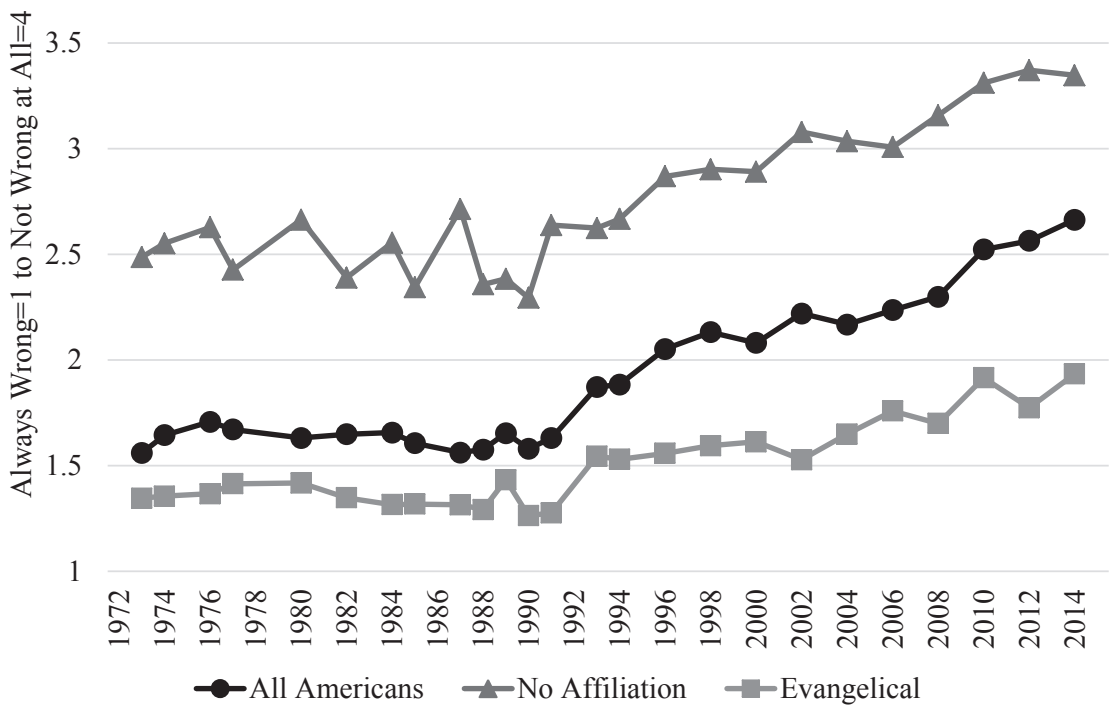

Fig. 3. Belief in morality of homosexuality over time.

Source: General Social Survey, 1973-2014.

a liberalizing trend over time. Evangelical attitudes toward same-sex relationships-like gender attitudes-are distinctive from those of other groups, but are they as adaptive as gender attitudes to the overall liberalizing trend?

Interaction terms for provide an effective way to test group rates of attitude change. Models 3 and 6 on Table 4 show that both evangelicals and Black Protestants demonstrate slower change than other groups on the morality of homosexuality and support for same-sex marriage. On the morality of homosexuality, mainline Protestants $(b=.012, \mathrm{p}<.001)$, Catholics $(b=.019, \mathrm{p}<.001)$, the unaffiliated $(b=.013, \mathrm{p}<.001)$, and those in the "other faith" category $(b=.022, \mathrm{p}<.001)$ liberalized more quickly than evangelicals. Catholics $(b=.021, \mathrm{p}<.01)$ and the unaffiliated $(b=.040, \mathrm{p}<.001)$ have moved to accept

5

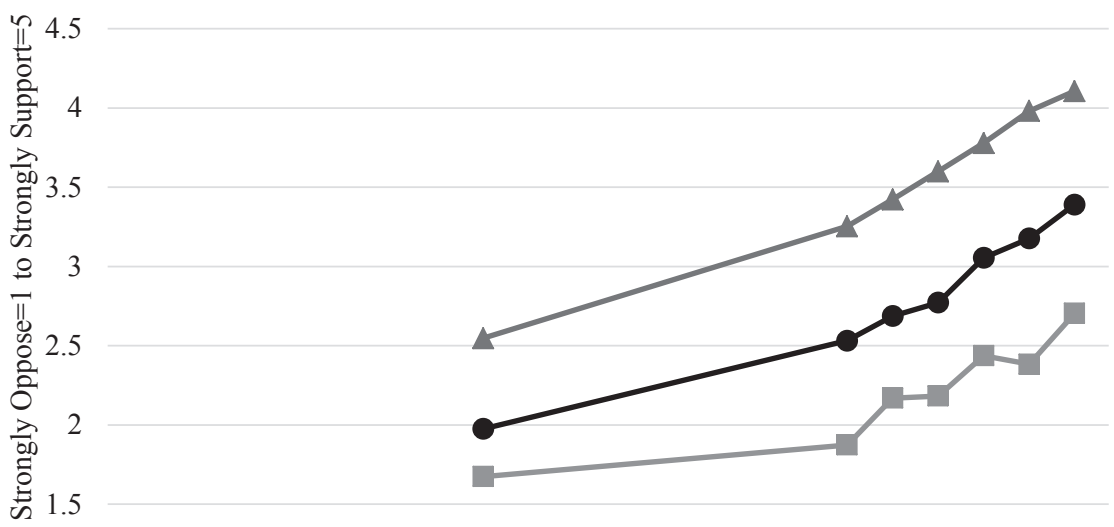

1

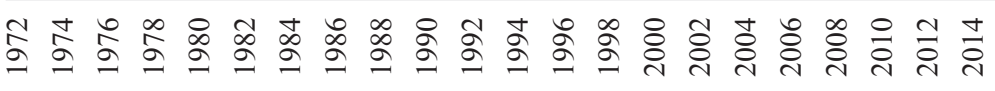

All Americans $\rightarrow$ No Affiliation $\rightarrow$ Evangelical

Fig. 4. Support for same-sex marriage over time.

Source: General Social Survey, 1988-2014. 
Table 4

Ordinal regression of religious groups and over-time interactions on morality of homosexuality and support for same-sex marriage.

\begin{tabular}{|c|c|c|c|c|c|c|}
\hline & \multicolumn{3}{|l|}{ Morality } & \multicolumn{3}{|l|}{ Marriage } \\
\hline & 1 & 2 & 3 & 4 & 5 & 6 \\
\hline \multicolumn{7}{|l|}{ Main Effects } \\
\hline Evangelical & - & - & - & - & - & - \\
\hline Black Protestant & $0.036(0.060)$ & $0.518^{* * *}(0.082)$ & $0.547^{* * *}(0.156)$ & $0.374^{* * *}(0.076)$ & $0.680^{* * *}(0.101)$ & $0.732^{* * *}(0.192)$ \\
\hline Mainline & $0.786^{* * *}(0.038)$ & $0.675^{* * *}(0.041)$ & $0.405^{* * *}(0.081)$ & $0.741^{* * *}(0.062)$ & $0.718^{* * *}(0.065)$ & $0.450^{* *}(0.152)$ \\
\hline Catholic & $1.004^{* * *}(0.037)$ & $0.811^{* * *}(0.040)$ & $0.399^{* * *}(0.082)$ & $0.997^{* * *}(0.055)$ & $0.890^{* * *}(0.057)$ & $0.547^{* * *}(0.144)$ \\
\hline No Affiliation & $2.061^{* * *}(0.045)$ & $1.756^{* * *}(0.047)$ & $1.456^{* * *}(0.098)$ & $1.759^{* * *}(0.064)$ & $1.519^{* * *}(0.066)$ & $0.734^{* * *}(0.204)$ \\
\hline Jewish & $2.535^{* * *}(0.088)$ & $2.136^{* * *}(0.094)$ & $1.825^{* * *}(0.164)$ & $1.958^{* * *}(0.155)$ & $1.711^{* * *}(0.160)$ & $1.296^{* * *}(0.368)$ \\
\hline Other Faith & $1.074^{* * *}(0.060)$ & $0.803^{* * *}(0.062)$ & $0.322^{*}(0.135)$ & $1.027^{* * *}(0.100)$ & $0.869^{* * *}(0.104)$ & $0.823^{* * *}(0.220)$ \\
\hline Year & $0.039^{* * *}(0.001)$ & $0.040^{* * *}(0.001)$ & $0.028^{* * *}(0.003)$ & $0.061^{* * *}(0.002)$ & $0.068^{* * *}(0.003)$ & $0.055^{* * *}(0.006)$ \\
\hline \multicolumn{7}{|l|}{ Interaction Effects } \\
\hline Evangelical*Year & & & - & & & - \\
\hline Black Protestant*Year & & & $-0.002(0.006)$ & & & $-0.004(0.010)$ \\
\hline Mainline*Year & & & $0.012^{* * *}(0.004)$ & & & $0.014(0.008)$ \\
\hline Catholic*Year & & & $0.019^{* * *}(0.003)$ & & & $0.019 *(0.007)$ \\
\hline No Affiliation*Year & & & $0.013^{* * *}(0.004)$ & & & $0.040^{* * *}(0.010)$ \\
\hline Jewish*Year & & & $0.015(0.008)$ & & & $0.023(0.020)$ \\
\hline Other Faith*Year & & & $0.022^{* * *}(0.006)$ & & & $0.002(0.011)$ \\
\hline Controls ${ }^{\mathrm{a}}$ & No & Yes & Yes & No & Yes & Yes \\
\hline Constant (Cut 1) & 2.146 & 1.432 & 1.173 & 0.918 & 0.083 & -0.160 \\
\hline Constant (Cut 2) & 2.398 & 1.715 & 1.456 & 1.740 & 0.968 & 0.725 \\
\hline Constant (Cut 3) & 2.812 & 2.173 & 1.915 & 2.352 & 1.632 & 1.391 \\
\hline Constant (Cut 4) & & & & 3.532 & 2.907 & 2.672 \\
\hline$N$ & 29,983 & 29,983 & 29,983 & 8,785 & 8,785 & 8,785 \\
\hline BIC & 53250.456 & 50061.611 & 50076.383 & 26089.061 & 25236.232 & 25265.590 \\
\hline
\end{tabular}

Note: Standard errors in parentheses; Models estimated with robust standard errors.

${ }^{*} p<.05,{ }^{* *} p<.01,{ }^{* * *} p<.001$.

a Analyses use the same controls as Table 2: female, race, age, parental status, marital status, female work status, region, education, and family income. Source: General Social Survey (Morality 1973-2014; Marriage 1988, 2004-2014)

same-sex marriage more quickly than have evangelicals. In sensitivity analyses examining just 2004 to 2014 , the coefficients for the religious group and year are similar on views of the morality of homosexuality, but smaller on same-sex marriage. In other words, evangelicals' views are continuing to lag on the morality of homosexuality at a similar rate as in the past, but in recent years their attitudes toward same-sex marriage are trending toward changing at the same rate as other groups.

Overall, these sexuality attitudes followed the first possible pattern discussed in the expectations: distinctive differences and slower attitude change among evangelicals. Gender attitudes and sexuality attitudes follow different patterns of change across American religious groups, suggesting that change in these attitudes is decoupled for some groups. Evangelical attitudes toward same-sex relationships are becoming increasingly distinctive, whereas their gender attitudes are more adaptive, paralleling the national trend. Therefore, attitudes toward same-sex relationships seem to be becoming more important for drawing symbolic boundaries and the expression of collective evangelical identity. The 2014 evangelical uptick in support for same-sex marriage, however, may indicate that this trend could shift in the future.

\subsection{Further analysis confirming different change patterns}

Fig. 1-4 showed that the gender and sexuality attitudes of the general population have followed different change patterns. Illustratively, gender attitudes changed more quickly than sexuality attitudes until 1994. From 1994 to 2000, sexuality attitudes liberalized while gender attitudes became more conservative. Since 2000, both types of attitudes have been changing quickly.

Further regression analyses confirm that gender and sexuality attitudes have followed different patterns across religious groups. Table 5 shows the effect of religious affiliation on gender attitudes over time with a linear term for year-instead of the spline function shown in Table 3-to make it more easily comparable to the same-sex relationship attitudes analyses. Observations from 1994 to 2014, the period of time that evangelical attitudes changed at the same rate as other groups in the spline function, are included. The table shows evangelical attitudes changed just as quickly as those of other groups from 1994 to 2014, confirming that gender and sexuality attitudes follow a different pattern of change across religious groups. ${ }^{21}$ The $^{2}$

\footnotetext{
${ }^{21}$ When including all years, the faster liberalization of mainline Protestants and Catholics from 1977 to 1994 shows up as a significant effect. In a sensitivity analysis, I examined the morality of homosexuality measure including only those cases from 1994 to 2014 to ensure that the linear term for gender attitudes presented in 5 is comparable to what is presented in Table 4. In this analysis, evangelical attitudes on the morality of homosexuality still changed more slowly than those of other groups.
} 
Table 5

Interaction effects of membership and linear year term on gender attitudes scale $(\mathrm{N}=13,509)^{\mathrm{a}}$.

\begin{tabular}{lll}
\hline & Model 1 & Model 2 \\
\hline Main Effects & & \\
Evangelical & - & - \\
Black Protestant & $0.225^{* * *}(0.042)$ & $0.157^{* * *}(0.042)$ \\
Mainline & $0.184^{* * *}(0.032)$ & $0.171^{* * *}(0.029)$ \\
Catholic & $0.228^{* * *}(0.030)$ & $0.179^{* * *}(0.028)$ \\
No Affiliation & $0.367^{* * *}(0.035)$ & $0.287^{* * *}(0.033)$ \\
Jewish & $0.486^{* * *}(0.070)$ & $0.336^{* * *}(0.064)$ \\
Other Faith & $0.176^{* * *}(0.051)$ & $0.097^{*}(0.048)$ \\
Year & $0.009^{* * *}(0.002)$ & $0.010^{* * *}(0.002)$ \\
Year Interaction Effects & & - \\
Evangelical ${ }^{*}$ Year & - & $0.000(0.003)$ \\
Black Protestant ${ }^{*}$ Year & $0.001(0.004)$ & $0.001(0.003)$ \\
Mainline*Year & $0.001(0.003)$ & $-0.003(0.002)$ \\
Catholic*Year & $-0.006^{*}(0.002)$ & $-0.003(0.003)$ \\
No Affiliation*Year & $-0.003(0.003)$ & $-0.004(0.006)$ \\
Jewish*Year & $-0.007(0.007)$ & $-0.004(0.004)$ \\
Other Faith*Year & $-0.008(0.004)$ & Yes \\
Controls & No & -0.167 \\
Constant & -0.301 & 13,509 \\
$N$ & 13,509 & 0.167 \\
$R^{2}$ & 0.035 & 26210.206 \\
BIC & 28069.815 & \\
\hline
\end{tabular}

Note: Standard errors in parentheses; Models estimated with robust standard errors.

${ }^{*} p<.05,{ }^{* *} p<.01,{ }^{* * *} p<.001$.

a Controls are female, race, age, parental status, marital status, female work status, region, education, and family income. Control values are similar to those in Table 2.

Source: General Social Survey 1994-2014

simple year term also allows us to see that American gender attitudes have not stagnated. In spite of the decline in attitudes from 1994 to 2000 shown in the spline function, American attitudes have liberalized significantly since $1994{ }^{22}$

\section{Discussion and conclusion}

This study used General Social Survey data to compare attitudes toward gender roles and same-sex relationships across American religious groups from the 1970s to 2014, considering three possible patterns for how evangelical attitudes relate to those of other groups: (1) they are similar; (2) they are different, but move together over time; (3) they are different and converge or diverge over time. The results show that gender attitudes fit the second pattern, and same-sex relationship attitudes the third. Evangelical gender attitudes regarding work and family issues are more conservative than those of all other groups, but are adaptive to broad trends, changing at a rate similar to those of other groups since 1994. Evangelical attitudes toward the morality of homosexuality and same-sex marriage are also more conservative than those of all other religious groups. Their rate of change, however, is slower than other religious groups, meaning that they are diverging over time. Separate patterns on the two issues suggest that gender and sexuality attitude change is decoupled, especially among evangelicals who are adapting more on gender while increasingly distinguishing themselves on same-sex relationships.

Gender attitudes differ across religious groups at any point in time, but all Christian groups and the unaffiliated have followed the same change pattern: liberalization in the late-1970s to mid-1990s, a shift toward traditionalism from the mid1990s to early 2000s, and then an upward trend until 2014. Mainline Protestant and Catholic gender attitudes did liberalize more quickly than evangelicals from 1977 to 1994, which suggests that gender roles used to be a more important site for distinction. But evangelicals did not differ from other Christian groups or the unaffiliated in their rate of attitude decline from 1994 to 2000 or in their rate of attitude resurgence from 2000 to 2014. Religious affiliation does not seem to affect gender attitude change in more recent years - though evangelicals are still less gender egalitarian than other groups. Therefore, on gender attitudes, evangelicals followed the second possible pattern with continued distinction, but rates of change similar to those of other groups.

The examination of attitudes toward same-sex relationships revealed different change patterns. Attitudes on the morality of sexuality began liberalizing quickly at the same time that gender attitudes moved back toward traditionalism (based on the trends across available years, support for same-sex marriage likely followed a similar pattern). Whereas evangelical gender attitudes moved in parallel to those of other Christian groups and the unaffiliated, their attitudes on the morality of

\footnotetext{
${ }^{22}$ A sensitivity analysis including both attitudes in the same model further confirms the differing change patterns. Though only about half the people were asked both questions due to the years the questions were asked and subsampling within years, an analysis of the sexuality attitudes examined in Table 4 with controls for gender attitudes-gender attitudes, year binaries, and interaction terms for these-does not alter the change patterns across religious groups-evangelical sexuality attitudes still change more slowly than those of the other groups.
} 
homosexuality and support for same-sex marriage-along with those of Black Protestants-changed more slowly. Therefore, on sexuality attitudes, evangelicals followed the third possible pattern of more conservative attitudes and a distinctly slower rate of change.

Gender and sexuality attitude change fit different patterns. Attitudes toward same-sex relationships began to liberalize in the mid-1990s, the same time that gender attitudes declined, indicating a decoupling of change-this is not to say that they are not still related, just that they are changing differently. ${ }^{23}$ Beyond the decoupling of change, groups differ in their location on the conservative-liberal spectrum on gender and sexuality attitudes. For example, Black Protestants were just as gender egalitarian as mainline Protestants and Catholics, but their attitudes toward same-sex relationships were more conservative. The distinctive patterns in rates of attitude change suggest an increasing importance of sexuality attitudes for the drawing of symbolic boundaries. Evangelicals now seem to be defining and distinguishing themselves more on their views toward samesex relationships than gender roles.

This study shows that religious affiliation cannot be used to explain the gender attitude decline in the mid-1990s noted by Cotter et al. (2011) and others. Nevertheless, it is possible that complementarian religious ideas diffused across other groups. Fig. 1 showed that evangelical and mainline Protestants diverged from one another in the late 1980s, which hints at the importance of the rise of the Christian Right and especially the prominence of the Moral Majority at that time (Schnabel, 2013). In the mid-1990s through 2000, both the non-denominational Promise Keeper's Christian men's movement and the Christian Coalition were at their peak. 2000 was a particularly important turning point in the decline of both movements for a variety of sociopolitical reasons (Schnabel, 2013, Bartkowski, 2004). Although these groups were most popular among evangelicals, they appealed to social conservatives across religious divides. The popularity of these groups at the same time that gender attitudes became more traditional suggests a connection; this popularity could also be indicative of a general essentialist backlash in conjunction with the rise of intensive mothering, which combines a rhetoric of choice and equality with an idealization of stay-at-home mothering (Cotter et al., 2011; Faludi, 1991; Stone, 2007). Indicative of the rising popularity of these ideas, one of the foundational books for attachment parenting and intensive mothering came out just before the attitude decline (Sears and Sears, 1993).

The results also demonstrate that gender attitudes have not "stalled" as proposed by Cotter et al. (2011), whose data went through $2008 .{ }^{24}$ Rather than stagnating, American gender attitudes have liberalized consistently both before and after a short period of decline. Since 2008, we have seen the highest levels of egalitarianism yet. Current liberalization, similar to past change, is happening at similar rates across religious groups. Rather than trying to understand why gender attitude change has slowed or stalled, the question future research may want to address is what caused gender attitudes to become more traditional while attitudes toward same-sex relationships continued to liberalize.

Why are evangelical attitudes toward same-sex relationships changing more slowly, and what might happen in the future? There are a few possibilities, but one likely explanation is that theology, history, and politics have linked conservative Christian identity and opposition to same-sex marriage. Evangelical "traditional values" are currently in more tension with the larger society on same-sex relationships than on work and family roles for women and men. There is a clear and widely shared evangelical view on same-sex relationships rooted in evangelical politics and literal interpretations of the Bible, but it would now be harder to determine and define any one shared evangelical position on gender, work, and family. When women had started joining the workforce but most Americans were still opposed to same-sex relationships, evangelicals distinguished themselves more on conservative gender roles and less on views toward same-sex relationships. Today, however, evangelical leaders can support working women and women politicians without facing much boundary policing from evangelicals in the pews (consider evangelical support for Sarah Palin), but would face backlash from some segments of evangelicalism for coming out in favor of same-sex marriage. Research suggests that evangelical affiliation and evangelical politics, of which same-sex marriage is a key issue, are so closely tied that people will shift their religious identity because of their political identity (Hout and Fischer, 2002; 2014). Slower change on views of same-sex relationships, therefore, could come both from evangelicals changing their views more slowly and the disaffiliation of some evangelicals with more liberal views on same-sex relationships.

Things may be changing, however. Following the nationwide legalization of same-sex marriage, the tension between traditional evangelical views on same-sex relationships and cultural norms of equality, especially among younger people, may become too strong for evangelical identity to continue to be defined by opposition to same-sex relationships. The uptick in support for same-sex marriage among evangelicals in 2014 and recent news about key evangelical leaders, such as Tony Campolo and David Neff, coming out in favor of same-sex marriage suggest that such a transition may happen sooner rather than later. Just as gender roles became a less important factor for expressing and policing evangelical identity, opposition to same-sex marriage could also become a less important factor and eventually be replaced in evangelical political rhetoric by other issues. For now, however, sexuality remains a key defining issue for American religions as demonstrated by public responses to same-sex marriage legalization and related debates about religious liberty.

\footnotetext{
${ }^{23}$ Polychoric correlations show that people with conservative gender attitudes continue to be more likely to have conservative attitudes toward same-sex relationships than people with more liberal gender attitudes.

${ }^{24}$ This is not to say that Cotter et al. (2011) were wrong. They made it clear that the question mark at the end of their title- "The End of the Gender Revolution?"- was important even though they did talk about gender attitudes as stalled. Furthermore, they were careful to only speculate tentatively about attitude change following 2008 (the last year in their sample).
} 
The results of this study suggest a three-stage process of religious tension and evangelical identity building that should be further tested in future research: (1) similarity, (2) distinction, and (3) adaptation. When all of society agrees that something is wrong, evangelicals are less likely to use that issue to distinguish themselves-for example, evangelical attitudes toward gender egalitarianism in 1977 and their attitudes toward same-sex relationships through the early 1990s were similar to the rest of American society because most Americans agreed that these were unacceptable. When an issue becomes contested, however, evangelicals tend to hold the "traditional" position and use it to distinguish themselves. When the vast majority of society subsequently shifts and the issue is no longer widely contested-as happened with slavery, racial segregation, interracial marriage, women joining the workforce, and now same-sex marriage (Schnabel, 2015)-the tension may become too great and American evangelicals then shift along with the broader society and distinguish themselves on newly contested issues.

In light of the decoupling of rates of change in gender and sexuality attitudes among evangelicals and Black Protestants, future work could consider the relationship between affiliation and attitudes on other issues of sexuality (i.e., sexual education, pornography, pre- and extra-marital sex, cohabitation, and abortion) and personhood (i.e., birth control, abortion, physician-assisted suicide, and stem cell research-(Schnabel, 2014; Schnabel and Breitwieser, 2015)) that are commonly debated on religious grounds in the public sphere. Finally, future research could compare the effect of religious affiliation on other changing attitudes to examine whether affiliation has a stronger or weaker effect on issues less commonly debated in religious terms - such as marijuana and vaccination.

Religious affiliation remains important for understanding Americans' gender and sexuality attitudes, but does not seem particularly important for understanding rates of gender attitude change. Religion, however, continues to be one of the most important factors keeping some Americans from supporting the recent nationwide legalization of same-sex marriage. Through social change, evangelicalism continues its pursuit of distinction-to be in but not of the world (Smith et al., 1998; Stark and Finke 2000)-by recreating a changing but still distinctive collective identity. Just as there was a shift from gender roles to same-sex relationships as key sites for symbolic boundary drawing, the future could reveal a shift from same-sex relationships to other sites of religious tension and identity building.

\section{References}

Adamczyk, Amy, Pitt, Cassady, 2009. Shaping attitudes about homosexuality: the role of religion and cultural context. Soc. Sci. Res. 38 (2), 338-351. Bartkowski, John, 2001. Remaking the Godly Marriage: Gender Negotiation in Evangelical Families. Rutgers University Press, New Brunswick, NJ. Bartkowski, John, Read, Jen'nan Ghazal, 2003. Veiled submission: gender, power, and identity among evangelical and muslim women in the United States. Qual. Sociol. 26 (1), 71-92.

Bartkowski, John, 2004. The Promise Keepers: Servants, Soldiers, and Godly Men. Rutgers University Press, New Brunswick, NJ.

Bartkowski, John, Hempel, Lynn M., 2009. Sex and gender traditionalism among conservative protestants: does the difference make a difference? J. Sci. Study Relig. 48 (4), 805-816.

Baunach, Dawn Michelle, 2011. Decomposing trends in attitudes toward gay marriage, 1988-2006. Soc. Sci. Q. 92 (2), $346-363$.

Baunach, Dawn Michelle, 2012. Changing same-sex marriage attitudes in American from 1988 through 2010. Public Opin. Q. 76 (2), $364-378$.

Bean, Lydia, Martinez, Brandon C., 2014. Evangelical ambivalence toward gays and lesbians. Sociol. Relig. 75 (3), $395-417$.

Bolzendahl, Catherine, Myers, Daniel J., 2004. Feminist attitudes and support for gender equality: opinion change in women and men, 1974-1998. Soc. Forces 83 (2), 759-790.

Brinkerhoff, Merlin B., MacKie, Marlene, 1984. Religious denominations' impact upon gender attitudes: some methodological implications. Rev. Relig. Res. 25 (4), 365-378.

Brinkerhoff, Merlin B., MacKie, Marlene, 1985. Religion and gender: a comparison of canadian and American student attitudes. J. Marriage Fam. 47 (2), 415-429.

Brooks, Clem, Bolzendahl, Catherine, 2004. The transformation of U.S. gender role attitudes: cohort replacement, social-structural change, and ideological learning. Soc. Sci. Res. 33 (1), 106-133.

Burn, Shawn Meghan, Busso, Julia, 2005. Ambivalent sexism, scriptural literalism, and religiosity. Psychol. Women Q. 29 (4), $412-418$.

Charles, Maria, Grusky, David B., 2005. Occupational Ghettos: the Worldwide Segregation of Women and Men. Standford University Press, Standford, CA. Cotter, David, Hermsen, Joan M., Vanneman, Reeve, 2011. The end of the gender revolution? Gender role attitudes from 1977 to 2008. Am. J. Sociol. 117 (1), 259-289.

Denton, Melinda Lundquist, 2004. Gender and marital decision making: negotiating religious ideology and practice. Soc. Forces 82 (3), 1151-1180. Dillon, Michele, 2014. Asynchrony in attitudes toward abortion and gay rights: the challenge to values alignment. J. Sci. Study Relig. 53 (1), 1-16.

Edgell, Penny, 2006. Religion and Family in a Changing Society. Princeton University Press, Princeton, NJ.

Edgell, Penny, Gerteis, Joseph, Hartmann, Douglas, 2006. Atheists as "Other": moral boundaries and cultural membership in American Society. Am. Sociol. Rev. 71 (2), 211-234.

Edgell, Penny, Docka, Danielle, 2007. Beyond the nuclear family? Familism and gender ideology in diverse religious communities. Sociol. Forum 22 (1), 25-50.

Edgell, Penny, 2012. A cultural sociology of religion: new directions. Annu. Rev. Sociol. 38 (1), $247-265$.

England, Paula, 2010. The gender revolution: uneven and stalled. Gend. Soc. 24 (2), 149-166.

Faludi, Susan, 1991. Backlash: the Undeclared War against American Women. Crown, New York.

Gallagher, Sally, Smith, Christian, 1999. Symbolic traditionalism and pragmatic egalitarianism. Gend. Soc. 13 (2), $211-233$.

Gallagher, Sally K., 2003. Evangelical Identity \& Gendered Family Life. Rutgers University Press, New Brunswick, NJ.

Gallagher, Sally K., 2004. Where are the antifeminist evangelicals? Evangelical identity, subcultural location, and attitudes toward feminism. Gend. Soc. 18 (4), 451-472.

Gerson, Kathleen, 2010. The Unfinished Revolution: How a New Generation Is Reshaping Family, Work, and Gender in America. Oxford University Press, New York.

Heath, Melanie, 2003. Soft-boiled masculinity: renegotiating gender and racial ideologies in the promise keepers movement. Gend. Soc. 17 (3), $423-444$. Hoffman, John P., Bartkowski, John, 2008. Gender, religious tradition and biblical literalism. Soc. Forces 86 (3), $1245-1272$.

Hout, Michael, Fischer, Claude S., 2002. Why more americans have no religious preference: politics and generations. Am. Sociol. Rev. 67 (2), 165-190.

Hout, Michael, Fischer, Claude S., October 2014. Explaining why more Americans have no religious preference: political backlash and generational succession, 1987-2012. Sociol. Sci. 1, 423-447.

Iannaccone, Laurence R., 1994. Why strict churches are strong. Am. J. Sociol. 99 (5), 1180-1211. 
Kenneavy, Kristin, 2012. Support for homosexuals' civil liberties: the influence of familial gender role attitudes across religious denominations. Soc. Forces 90 (4), 1347-1375.

Lamont, Michèle, Molnár, Virág, 2002. The study of boundaries in the social sciences. Annu. Rev. Sociol. 28, $167-195$.

Lewis, Gregory B., Gossett, Charles W., 2008. Changing public opinion on same-sex marriage: the case of California. Polit. Policy 36 (1), 4-30.

Linneman, Thomas J., 2004. Homophobia and hostility: christian conservative reactions to the political and cultural progress of lesbians and gay men. Sex. Res. Soc. Policy 1 (2), 56-76.

Loftus, Jeni, 2001. America's liberalization in attitudes toward homosexuality, 1973-1998. Am. Sociol. Rev. 66 (5), $762-782$.

Luker, Kristin, 2006. When Sex Goes to School. Norton, New York.

McVeigh, Rory, Diaz, Maria-Elena D., 2009. Voting to ban same-sex marriage: interests, values, and communities. Am. Sociol. Rev. 74 (6), 891-915.

Moore, Laura M., Vanneman, Reeve, 2003. Context matters: effects of the proportion of fundamentalists on gender attitudes. Soc. Forces 82 (1), 115-139.

Olson, Laura R., Cadge, Wendy, Harrison, James T., 2006. Religion and public opinion about same-sex marriage. Soc. Sci. Q. 87 (2), 340-360.

Pampel, Fred, 2011. Cohort changes in the socio-demographic determinants of gender egalitarianism. Soc. Forces 89 (3), $961-982$.

Peek, Charles W., George, D. Lowe, Williams, L. Susan, 1991. Gender and god's word: another look at religious fundamentalism and sexism. Soc. Forces 69, 1205-1221.

Perry, Samuel L., 2015. Bible beliefs, conservative religious identity, and same-sex marriage support: examining main and moderating effects. J. Sci. Study Relig. Forthcoming.

Petersen, Larry R., Donnenwerth, Gregory V., 1998. Religion and declining support for traditional beliefs about gender roles and homosexual rights. Sociol. Relig. 59 (4), 353-371.

Powell, Brian, Bolzendahl, Catherine, Geist, Claudia, Steelman, Lala Carr, 2010. Counted Out: Same-Sex Relations and Americans' Definitions of Family. Russell Sage Foundation, New York.

Raftery, Adrian E., 1995. Bayesian model selection in social research. Sociol. Methodol. 25 (1), 111-163.

Schnabel, Landon, 2013. When fringe goes mainstream: a sociohistorical content analysis of the christian coalition's contract with the American family and the republican party platform. Politics Relig. Ideol 14 (1), 94-113.

Schnabel, Landon, 2014. The question of subjectivity in three emerging feminist science studies frameworks: feminist postcolonial science studies, new feminist materialisms, and queer ecologies. Womens Stud. Int. Forum 44 (3), 10-16.

Schnabel, Landon, 2015. Toward a standpoint hermeneutic: the case of the evangelical gender subordination debate. Claremont J. Relig 4 (1), 86-112.

Schnabel, Landon, Breitwieser, Lindsey, 2015. Recent advances in feminist science and technology studies: reconceptualizing subjectivity and knowledge. Adv. Gender Res 20 (1), 43-63.

Schnittker, Jason, Freese, Jeremy, Powell, Brian, 2003. Who are feminists and what do they believe? The role of generations. Am. Sociol. Rev. 68 (4), $607-622$.

Sears, William, Sears, Martha, 1993. The Baby Book: Everything You Need to Know about Your Baby — from Birth to Age Two. Little, Brown, and Company, Boston, MA.

Sherkat, Darren E., Mattias de Vries, Kylan, Creek, Stacia, 2010. Race, religion, and opposition to same-sex marriage. Soc. Sci. Q. 91 (1), 80-98.

Sherkat, Darren E., Powell-Williams, Melissa, Maddox, Gregory, de Vries, Kylan Mattias, 2011. Religion, politics, and support for same-sex marriage in the United States, 1988-2008. Soc. Sci. Res. 40 (1), 167-180.

Smith, Christian, Emerson, Michael, Gallagher, Sally, Kennedy, Paul, Sikkink, David, 1998. American Evangelicalism: Embattled and Thriving. University of Chicago Press, Chicago, IL.

Stark, Rodney, Finke, Roger, 2000. Acts of Faith: Explaining the Human Side of Religion. University of California Press, Berkeley, CA.

Steensland, Brian, Park, Jerry Z., Regnerus, Mark D., Robinson, Lynn D., Wilcox, W. Bradford, Woodbury, Robert D., 2000. The measure of American religion: toward improving the state of the art. Soc. Forces 79 (1), 291-318.

Stone, Pamela, 2007. Opting Out? Why Women Really Quit Careers and Head Home. University of California Press, Berkeley, CA.

Swidler, Ann, 1986. Culture in action: symbols and strategies. Am. Sociol. Rev. 51 (2), 273-286.

Tranby, Eric, Zulkowski, Samanth E., 2012. Religion as cultural power: the role of religion in influencing Americans' symbolic boundaries around gender and sexuality. Sociol. Compass 6 (11), 870-882.

Wilcox, W. Bradford, 2004. Soft Patriarchs, New Men: How Christianity Shapes Fathers and Husbands. University of Chicago Press, Chicago.

Winship, Christopher, Radbill, Larry, 1994. Sampling weights and regression analysis. Sociol. Methods \& Res. 23 (2), $230-257$.

Woodberry, Robert D., Park, Jerry Z., Kellstedt, Lyman A., Regnerus, Mark D., Steensland, Brian, 2012. The measure of American religious traditions: theoretical and measurement considerations. Soc. Forces 91 (1), 65-73. 